\title{
Postemergence Control of Annual Bluegrass with Mesotrione in Kentucky Bluegrass
}

\author{
Joshua J. Skelton ${ }^{1}$, William Sharp ${ }^{2}$, and Bruce E. Branham ${ }^{3,4}$ \\ University of Illinois Urbana-Champaign, Department of Crop Sciences, \\ Landscape Horticulture Research Center, 2308 South Lincoln Avenue, \\ Urbana, IL 61801
}

Additional index words. Poa annua, Poa pratensis, HPPD-inhibitior, herbicide rate, application interval

\begin{abstract}
Six field trials were conducted in 2009 and 2010 to study postemergence control of annual bluegrass (Poa annua L. var. Hausskn Timm) in kentucky bluegrass (Poa pratensis $\mathrm{L}$.) with mesotrione. Mesotrione was applied at 11 different rate and application intervals to an area of kentucky bluegrass that was naturally infested with annual bluegrass. Mesotrione rates of $56 \mathrm{~g} \cdot \mathrm{ha}^{-1}$ applied two or three times per week for a total of 10 applications or $84 \mathrm{~g} \cdot \mathrm{ha}^{-1}$ applied two times per week for a total of seven applications provided consistent control of annual bluegrass but required significant application labor and resulted in minor kentucky bluegrass injury. Other treatments that required fewer applications, $110 \mathrm{~g} \cdot \mathrm{ha}^{-1}$ applied twice per week for five applications or $186 \mathrm{~g} \cdot \mathrm{ha}^{-1}$ per week for three applications, also achieved high levels of control under high air temperatures, but control levels can vary significantly as temperatures fluctuate and seasons change. Mesotrione can successfully control annual bluegrass in kentucky bluegrass when frequent applications at low rates are applied or when environmental conditions are conducive to control.
\end{abstract}

Annual bluegrass (Poa annua L. var. Hausskn Timm) is a very difficult weed species to control in cool-season turf areas. Prolific seed production and germination coupled with tolerance to low mowing heights and soil compaction makes annual bluegrass $(A B G)$ a very invasive weed, but lack of heat and drought tolerance, along with susceptibility to many pests, makes it difficult to maintain (Beard et al., 1978). Under highly maintained turf settings, ABG converts to a perennial life cycle over time requiring the use of a postemergence herbicide application for eradication (Branham et al., 2010). The selective control of ABG in cool-season turf, especially kentucky bluegrass (Poa pratensis L.), can be challenging as a result of limited herbicide options (Reicher et al., 2011).

Mesotrione is a new herbicide for use on turf that has postemergence activity on many broadleaf and grass weed species. Mesotrione was introduced for agricultural use as Callisto ${ }^{\circledR} 4 \mathrm{~S}$ (Syngenta Crop Protection, Greensboro, NC) and was registered for turf use in 2008 as Tenacity ${ }^{\circledR} 4 \mathrm{~S}$ (Syngenta Professional Products, Greensboro, NC). Developed after the naturally occurring allelochemical, leptospermone, mesotrione works by inhibiting the enzyme 4-hydroxyphenylpyruvate

\footnotetext{
Received for publication 30 Sept. 2011. Accepted for publication 25 Dec. 2011.

${ }^{1}$ Graduate Research Assistant.

${ }^{2}$ Research Agronomist.

${ }^{3}$ Professor.

${ }^{4}$ To whom reprint requests should be addressed; e-mail bbranham@illinois.edu.
}

dioxygenase of the biosynthesis pathway of plastoquinone and tocopherols (Beaudegnies et al., 2009). Tocopherols are antioxidants that scavenge for damaging radicals, and plastoquinone is an electron carrier used in Photosystem II. The production of carotenoids is also ended because of the requirement for plastoquinone as a precursor. Carotenoids are light-harvesting antenna structures responsible for quenching high-energy states of chlorophyll (Beaudegnies et al., 2009). By quenching chlorophyll, carotenoids reduce the production of destructive reactive oxygen species in the plant. When carotenoids are absent, lipids and proteins are damaged by radicals and reactive oxygen species, leading to the disassembly of the photosynthetic complex and eventually destruction of all leaf pigments, which gives plants the characteristic bleached look from mesotrione (Beaudegnies et al., 2009).

Mesotrione is a selective herbicide resulting from plant-specific rates of metabolism (Mitchell et al., 2001). In grain sorghum, mesotrione-tolerant cultivars metabolized mesotrione more rapidly than susceptible cultivars (Abit and Al-Khatib, 2009). Differential rates of metabolism allow mesotrione to be used as a selective herbicide to control weed species while preserving turf species, but may also limit weed control. Species not able to metabolize mesotrione rapidly will show symptoms of injury but may still be able to metabolize mesotrione before fatal injury occurs. This is the situation with ABG and the foundation for this research.

The current label for mesotrione use in turf states that $\mathrm{ABG}$ is not controlled with mesotrione (Anonymous, 2009). Mesotrione has been shown to provide postemergence control of $\mathrm{ABG}$ under agricultural settings, so there is potential to use mesotrione in turf to control ABG (Armel et al., 2009). Previous research in turf has shown that mesotrione can control ABG with pre-emergence applications, but control with postemergence applications occurs only in the fall (Hoiberg and Minner, 2010; Reicher et al., 2011). Furthermore, Reicher et al. (2011) described postemergence control of ABG as inconsistent. The objective of this study was to determine the rate and application interval of mesotrione that will yield the greatest postemergence control of ABG. Finding a rate and application interval that can be used throughout the year could allow mesotrione to be an effective option for postemergence ABG control in cool-season turf.

\section{Materials and Methods}

Plant culture. Experiments were initiated on 27 May and 25 July 2009 and 3 May, 7 June, 5 July, and 11 Oct. 2010 at the Landscape Horticulture Research Center on the University of Illinois campus. The trials were conducted in a mixed stand of kentucky bluegrass (KBG) and ABG. The Oct. 2010 trial was conducted on the KBG cultivar Odyssey, and all other trials were performed on a KBG cultivar blend of 'Total Eclipse', 'Award', and 'Excursion'. Annual bluegrass comprised more than $50 \%$ of the turf area and naturally infested the area. The turf stand was maintained at $2.2 \mathrm{~cm}$ and was mowed two to three times per week to simulate a golf course fairway. The soil type was a Flanagan silt loam (fine, smectic, mesic, aquic argiudolls) with a $\mathrm{pH}$ of 6.8 , sand content of $125 \mathrm{~g} \cdot \mathrm{kg}^{-1}$, silt content of $588 \mathrm{~g} \cdot \mathrm{kg}^{-1}$, and clay content of $287 \mathrm{~g} \cdot \mathrm{kg}^{-1}$. The area was irrigated as needed to ensure no water stress occurred and was fertilized at $147 \mathrm{~kg}$ nitrogen/ha/year with three applications of commercial fertilizers.

Herbicide treatments. Turf plots measuring $1.2 \mathrm{~m} \times 1.8 \mathrm{~m}$ were treated with mesotrione, as Tenacity ${ }^{\circledR}$ 4S (Syngenta Professional Products) at 11 different rate and application intervals (Table 1). Trials in 2009 had fewer treatments than trials in 2010 because of the addition of new treatments after 1 year of research. All treatment rate combinations were selected to apply the maximum annual application rate of mesotrione, $0.56 \mathrm{~kg} \cdot \mathrm{ha}^{-1}$, permitted by the current label (Syngenta Professional Products). As recommended by the current label, a non-ionic surfactant (Activator 90; Loveland Industries, Greeley, CO) was added at $0.25 \% \mathrm{v} / \mathrm{v}$ to all treatments. Treatments were applied with a $\mathrm{CO}_{2}$-pressurized sprayer calibrated to deliver $470 \mathrm{~L} \cdot \mathrm{ha}^{-1}$ at $0.27 \mathrm{MPa}$. The spray boom was composed of four flat-fan nozzles (TeeJet 8002 flat fan spray nozzles; Spraying Systems Co., Roswell, GA) spaced $25 \mathrm{~cm}$ apart and operated at a height of $60 \mathrm{~cm}$. Treatment schedules (Table 1) were applied at the same time of day when possible.

Data collection. Visual ABG injury symptoms were rated weekly on a $0 \%$ to $100 \%$ 
Table 1. Control of annual bluegrass 8 weeks after initial application from various rates and application timings of mesotrione.

\begin{tabular}{|c|c|c|c|c|c|c|c|c|c|}
\hline \multirow{3}{*}{$\begin{array}{l}\text { Rate } \\
\left(\mathrm{g} \cdot \mathrm{ha}^{-1}\right)\end{array}$} & \multirow{3}{*}{$\begin{array}{l}\text { Application } \\
\text { schedule }\end{array}$} & \multirow{3}{*}{$\begin{array}{c}\text { Total } \\
\text { applications }\end{array}$} & \multirow{3}{*}{$\begin{array}{c}\text { Treatment } \\
\text { duration in days }\end{array}$} & \multicolumn{6}{|c|}{ Expt. initiation } \\
\hline & & & & May 2-09 & July 2009 & May 2010 & June 2010 & July 2010 & October 2010 \\
\hline & & & & \multicolumn{6}{|c|}{ Percent annual bluegrass control } \\
\hline 56 & M W F & 10 & 21 & $85 \mathrm{a}^{2}$ & $93 \mathrm{a}$ & $40 \mathrm{~b}$ & $96 a$ & $88 \mathrm{a}$ & $68 \mathrm{a}$ \\
\hline 186 & M (every 2 weeks) & 3 & 28 & $\mathrm{y}$ & & $3 \mathrm{c}$ & $0 \mathrm{~d}$ & $27 \mathrm{~b}$ & $100 \mathrm{a}$ \\
\hline 186 & M & 3 & 14 & & & $3 \mathrm{c}$ & $58 \mathrm{abc}$ & $79 \mathrm{a}$ & $82 \mathrm{a}$ \\
\hline 186 & M Th & 3 & 7 & & & $3 \mathrm{c}$ & $20 \mathrm{~cd}$ & $70 \mathrm{a}$ & $23 \mathrm{~b}$ \\
\hline 186 & M W F & 3 & 5 & $0 \mathrm{c}$ & $51 \mathrm{c}$ & $3 \mathrm{c}$ & $0 \mathrm{~d}$ & $31 \mathrm{~b}$ & $0 \mathrm{~b}$ \\
\hline 110 & M & 5 & 28 & $57 \mathrm{~b}$ & $41 \mathrm{c}$ & $15 \mathrm{c}$ & $43 \mathrm{bc}$ & $92 \mathrm{a}$ & $53 \mathrm{a}$ \\
\hline $\begin{array}{l}220 \text { followed } \\
\text { by } 110\end{array}$ & M Th & 4 & 10 & & & $3 \mathrm{c}$ & $85 \mathrm{a}$ & $65 \mathrm{a}$ & $5 \mathrm{~b}$ \\
\hline 84 & M Th & 7 & 21 & & $95 \mathrm{a}$ & & & $62 \mathrm{a}$ & $86 \mathrm{a}$ \\
\hline
\end{tabular}

${ }^{2}$ Means followed by the same letter are not significantly different according to Fisher's least significant difference test $(P=0.05)$.

${ }^{\mathrm{y}} \mathrm{All}$ treatments were not used in all trials and are indicated by an empty space.

scale, where $0 \%$ was completely green tissue and $100 \%$ represented complete necrosis. In the Oct. 2010 trial, data were also collected weekly for $\mathrm{KBG}$ visual injury on a $0 \%$ to $100 \%$ scale because the KBG cover was much higher than the other trials. Percent control was calculated from initial and final visual estimates of $\mathrm{ABG}$ populations 8 weeks after initial application.

Statistical analysis. Before statistical analysis, data from non-treated plots were removed to stabilize variance (Corbett et al., 2004). Annual bluegrass control data from July 2009, May 2010, and Oct. 2010 were transformed with a logarithmic transformation to meet the assumptions of analysis of variance, whereas the remaining trials and data on KBG injury did not require any transformation (Kuehl, 2000). All data are presented as nontransformed, i.e., percent control. Data were analyzed using Proc Mixed (SAS, 2008), and means were separated using the least significant difference test at $\alpha=0.05$. Regression analysis was conducted using Proc Reg (SAS, 2008) on ABG control, application frequency, and temperature.

\section{Results}

Annual bluegrass injury. There was a significant interaction among trial, treatment, and weekly injury rating, so each trial was analyzed individually. To summarize the data overall treatments and trials, three treatments were selected that varied in the level of ABG control (Fig. 1A-C). Mesotrione at 56 $\mathrm{g} \cdot \mathrm{ha}^{-1}$ applied three times per week for a total of 10 applications resulted in high levels of ABG control, whereas $110 \mathrm{~g} \cdot \mathrm{ha}^{-1}$ per week for five applications and $186 \mathrm{~g} \cdot \mathrm{ha}^{-1}$ applied three times per week for three applications were less effective (Table 1). Treatments that provided ABG control produced high levels of foliar injury, and that injury persisted until the ABG died (Fig. 1A-C). All treatments resulted in ABG injury, but injury did not always result in control. Mesotrione applied at $110 \mathrm{~g} \cdot \mathrm{ha}^{-1}$ per week for five applications and $186 \mathrm{~g} \cdot \mathrm{ha}^{-1}$ three times per week for three applications triggered injury in $\mathrm{ABG}$, but the injury eventually decreased and little to no ABG control resulted (Fig. 1A-C). Applying

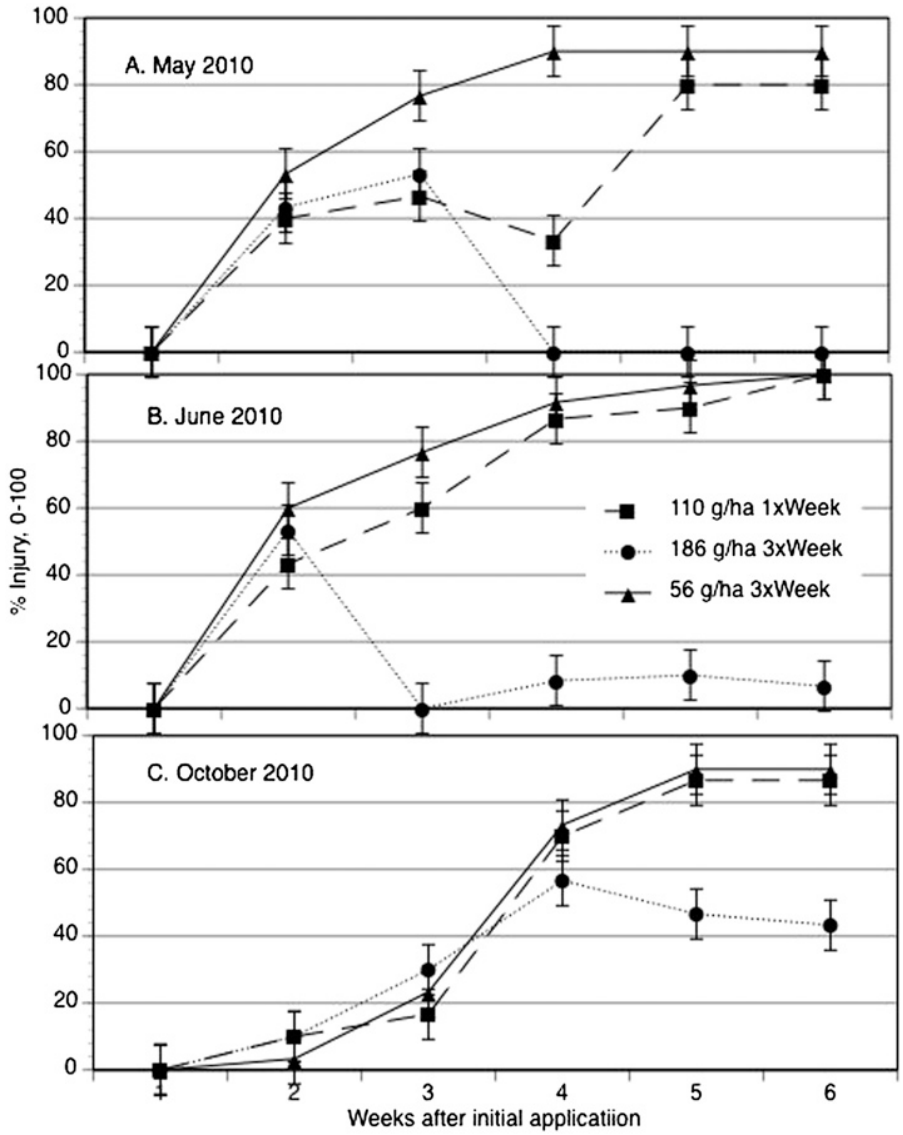

Fig. 1. (A-C) Annual bluegrass injury from mesotrione rates of $56 \mathrm{~g} \cdot \mathrm{ha}^{-1}(10$ applications three times per week), $110 \mathrm{~g} \cdot \mathrm{ha}^{-1}$ (five applications once per week), and $186 \mathrm{~g} \cdot \mathrm{ha}^{-1}$ (three applications three times per week) during May, July, and Oct. 2010 field trials. Error bars represent pooled SE of treatment means. Overlapping bars indicate no significant difference.

$56 \mathrm{~g} \cdot \mathrm{ha}^{-1}$ three times per week for 10 applications gave a consistent pattern of increasing $\mathrm{ABG}$ injury that reached a maximum at 4 to 5 weeks after initial treatment. Although ABG injury was severe in each trial from this treatment, control levels ranged from $40 \%$ to $88 \%$ (Table 1), indicating severe injury does not always lead to high levels of ABG control.

Annual bluegrass control. There was a significant interaction between treatment and trial, so each trial was analyzed individually. Mesotrione applications resulted in
ABG control; however, the effectiveness of various application schedules differed substantially between trials (Table 1). The only trial that did not produce at least one treatment with ABG control above $80 \%$ was May 2010. All other trials produced multiple treatments with acceptable (greater than $80 \%$ ) control (Table 1). Applications of 56 $\mathrm{g} \cdot \mathrm{ha}^{-1}$ two or three times per week for 10 applications or $84 \mathrm{~g} \cdot \mathrm{ha}^{-1}$ two times per week for seven applications consistently yielded superior ABG control. Applications of 56 $\mathrm{g} \cdot \mathrm{ha}^{-1}$ applied two or three times per week for 
10 applications provided the highest level of control in five of six trials. Applying $84 \mathrm{~g} \cdot \mathrm{ha}^{-1}$ twice per week for seven applications provided the highest level of control in the three trials in which it was included (Table 1). Other treatments were less consistent than these three treatments. For example, 186 $\mathrm{g} \cdot \mathrm{ha}^{-1}$ applied three times on a 14-d interval provided outstanding control in the Oct. 2010 trial but provided poor control in the May, June, and July 2010 trials. One treatment regime, $186 \mathrm{~g} \cdot \mathrm{ha}^{-1}$, applied three times on a 2-d interval provided poor control in each trial.

Kentucky bluegrass injury. Kentucky bluegrass injury data were not collected during the first five trials because the population of KBG was too low to accurately observe injury; however, injury data were collected in the Oct. 2010 trial. During this trial, KBG injury was not observed from any treatment for 2 weeks after the initial herbicide application (Table 2). At 3 weeks after initial application, injury symptoms including discoloration and slight bleaching were observed in some treatments, and at 4 weeks after application, all treatments showed some degree of bleaching injury (Table 2). After 4 weeks, however, the degree of bleaching decreased for the majority of treatments. At the end of 6 weeks, treatments of $56 \mathrm{~g} \cdot \mathrm{ha}^{-1}$ applied three times per week and $84 \mathrm{~g} \cdot \mathrm{ha}^{-1}$ applied twice per week were the only treatments still displaying statistically significant injury (Table 2). Injury from these two treatments would be considered unacceptable, and the turf did not recover completely until the next spring.

\section{Discussion}

Temperature influences control. Differences in ABG control levels can be attributed to many factors, but the weather during each trial seems the most likely reason. Increasing temperatures have been shown to increase weed control from mesotrione (Johnson and Young, 2002). However, McCurdy et al. (2008) working with perennial ryegrass did not observe a response to temperature. Also, irradiance levels and relative humidity may influence mesotrione activity (Johnson and Young, 2002; McCurdy et al., 2008).

During these trials, air temperatures and application timing interact to dramatically affect ABG control (Tables 1 and 3). In May and Oct. 2010, the temperatures were much lower during the first 3 weeks than the other trials (Table 3). In the May trial, temperatures rose beginning in the fourth week, whereas the temperatures in the October trial dropped further beginning in the fourth week leading to different responses to mesotrione in these two trials. In May 2010, only two treatments provided significant ABG control. These two treatments were the only treatments that had applications that extended into the fourth and fifth weeks of the experiment when average temperatures were much higher. In Oct. 2010, however, the temperature dropped after the first 3 weeks but high levels of control were

Table 2. Kentucky bluegrass injury from mesotrione treatment combinations in Oct. 2010.

\begin{tabular}{|c|c|c|c|c|c|c|c|}
\hline \multirow{2}{*}{$\begin{array}{l}\text { Rate } \\
\left(\mathrm{g} \cdot \mathrm{ha}^{-1}\right)\end{array}$} & \multirow{2}{*}{$\begin{array}{l}\text { Application } \\
\text { schedule }\end{array}$} & \multicolumn{6}{|c|}{ Percent kentucky bluegrass injury ${ }^{z}$} \\
\hline & & $1 \mathrm{WAIT}^{\mathrm{y}}$ & $2 \mathrm{WAIT}$ & 3 WAIT & 4 WAIT & 5 WAIT & $6 \mathrm{WAIT}$ \\
\hline 56 & M W F & 0.0 & 0.0 & 3.3 & $16.6^{*}$ & $25.0 * *$ & $26.6^{* *}$ \\
\hline 56 & $\mathrm{M} \mathrm{Th}$ & 0.0 & 0.0 & 0.0 & $13.3 *$ & $11.6 *$ & 10.0 \\
\hline 186 & M (every 2 weeks) & 0.0 & 0.0 & 0.0 & $10.0^{*}$ & 6.6 & 6.6 \\
\hline 186 & $\mathrm{M}$ & 0.0 & 0.0 & 3.3 & $16.6^{*}$ & $11.6^{*}$ & 6.6 \\
\hline 186 & M Th & 0.0 & 0.0 & $10 *$ & $16.6^{*}$ & 6.6 & 6.6 \\
\hline 186 & M W F & 0.0 & 0.0 & 6.6 & $13.3^{*}$ & 3.3 & 0.0 \\
\hline 110 & M W F & 0.0 & 0.0 & $16.6^{*}$ & $20.0 * *$ & $10.0 *$ & 6.6 \\
\hline 110 & M Th & 0.0 & 0.0 & 0.0 & $10.0^{*}$ & 0.0 & 0.0 \\
\hline 110 & M & 0.0 & 0.0 & 0.0 & 3.3 & 0.0 & 0.0 \\
\hline $\begin{array}{l}220 \text { followed } \\
\text { by } 110\end{array}$ & M Th & 0.0 & 0.0 & 0.0 & $10.0^{*}$ & 0.0 & 0.0 \\
\hline 84 & M Th & 0.0 & 0.0 & 0.0 & $16.6^{*}$ & $20.0 * *$ & $20.0 * *$ \\
\hline
\end{tabular}

${ }^{\mathrm{y}}$ Week after initial application

***Treatments statistically different from 0 ( $P \leq 0.05$ or $P \leq 0.001$, respectively).

Table 3. Average weekly air temperatures following treatment initiation.

\begin{tabular}{|c|c|c|c|c|c|c|}
\hline & $\begin{array}{l}\text { May } \\
2009\end{array}$ & $\begin{array}{c}\text { July } \\
2009\end{array}$ & $\begin{array}{l}\text { May } \\
2010\end{array}$ & $\begin{array}{l}\text { June } \\
2010\end{array}$ & $\begin{array}{c}\text { July } \\
2010\end{array}$ & $\begin{array}{c}\text { Oct. } \\
2010\end{array}$ \\
\hline Number of treatments with control ${ }^{\mathrm{z}}$ & 3 & 3 & 0 & 3 & 5 & 4 \\
\hline Temp. $\left({ }^{\circ} \mathrm{C}\right) 1$ week after application & 21.1 & 22.0 & 14.8 & 23.3 & 25.4 & 15.3 \\
\hline 2 weeks after application & 19.5 & 20.7 & 15.5 & 24.7 & 25.6 & 14.0 \\
\hline 3 weeks after application & 22.9 & 24.1 & 17.1 & 25.4 & 26.0 & 10.6 \\
\hline 4 weeks after application & 27.9 & 23.2 & 24.7 & 22.1 & 24.8 & 5.6 \\
\hline 5 weeks after application & 25.0 & 20.3 & 23.1 & 25.4 & 25.4 & 11.9 \\
\hline 6 weeks after application & 19.9 & 16.4 & 22.4 & 25.8 & 28.6 & 3.6 \\
\hline
\end{tabular}

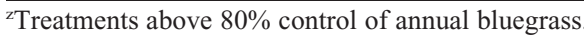

still observed in this trial, and one treatment, $186 \mathrm{~g} \cdot \mathrm{ha}^{-1}$ applied three times on a 14-d interval, gave $100 \% \mathrm{ABG}$ control but in other trials, it performed poorly. These results indicate that $\mathrm{ABG}$ response to mesotrione differs dramatically with temperature and season and reinforces the results of Reicher et al. (2011) who obtained acceptable ABG control with late-season mesotrione applications. The decline in temperatures in the October trial may reduce the metabolism of mesotrione by $\mathrm{ABG}$, allowing damaging concentrations of mesotrione to remain in the plant long enough to create high levels of control as shown by Mitchell et al. (2001).

In July 2010, the average temperature was the highest of all the trials (Table 3 ), and a number of treatments provided good to excellent control (Table 1). During the first 3 weeks after trial initiation, temperatures averaged $25.7{ }^{\circ} \mathrm{C}$, and five treatments provided greater than $80 \%$ control and seven greater than $70 \%$ control under these conditions. Higher temperatures may increase control levels as a result of the increase in photosynthesis and other metabolic reactions, leading to an increased concentration of radical and reactive oxygen species in the plant. Because mesotrione can reduce free radical scavenging and quenching, the higher concentration of radicals will lead to more damage to susceptible plants. Mesotrione treatments that featured multiple, frequent applications yielded excellent control when temperatures were above $20{ }^{\circ} \mathrm{C}$ during the first 3 weeks after trial initiation (Table 1); conversely, treatments with few applications or a long period of time between applications were not as successful in controlling $\mathrm{ABG}$ under warmer conditions. Metabolism of mesotrione is the most likely explanation because the rapid metabolism of mesotrione during high temperatures will reduce the concentration in the plant quickly, thus reducing herbicidal activity. Mitchell et al. (2001) showed that species are controlled better when mesotrione is metabolized slowly and a high concentration is maintained in the plant.

Application frequency affects control. Application rate and frequency are the main factors that determine how much mesotrione enters the ABG plant. During the hot July 2010 trial, ABG recovered rapidly from mesotrione at $186 \mathrm{~g} \cdot \mathrm{ha}^{-1}$ applied three times on 2-d intervals, whereas injury from 56 g.ha $\mathrm{h}^{-1}$ applied three times per week for 10 applications steadily increased for the first 2 weeks of the trial and then remained injured for the rest of the trial (Fig. 1B). Frequent and prolonged applications overcome the rapid metabolism of mesotrione, keeping mesotrione concentrations elevated enough to cause injury leading to ABG control during periods of high temperatures. Applying mesotrione as frequently as three times per week is an attempt to overcome the rapid metabolism of mesotrione by ABG. However, best overall control appears to result from a combination of application rate, timespan of applications, and temperature. The three treatment regimes that gave the most consistent and highest level of control took between 21 and $31 \mathrm{~d}$ to complete the applications (Table 1). Weekly applications of mesotrione at 186 or $110 \mathrm{~g} \cdot \mathrm{ha}^{-1}$ were, in general, not as effective as comparable rates of mesotrione applied more frequently. The exception was the Oct. 2010 trial when $186 \mathrm{~g} \cdot \mathrm{ha}^{-1}$ applied 
on a 14-d interval for three applications gave outstanding control (Table 1).

The response of $\mathrm{ABG}$ to application frequency was estimated by using treatments applied at $186 \mathrm{~g} \cdot \mathrm{ha}^{-1}$ at application intervals of 2 to $14 \mathrm{~d}$ for the trials conducted in 2010 (Figs. 2 and 3). The May 2010 trial was omitted as a result of low control levels. Heterogeneous error variances did not allow a combined analysis of all three trials, but the June and July trials could be combined, and the October trial was analyzed separately. When reviewing the combined June and July and the October data, application frequency is significant in both data sets $(P=0.0305$, Fig. 2; $P=0.002$, Fig. 3). However, the relationship between application frequency and percent control differs for the trials in June and July compared with October. The
June and July trials did not show a significant linear response $(P=0.77)$ but instead display a quadratic response with maximum control with an application every $7.8 \mathrm{~d}(P=0.009$; Fig. 2). In contrast, $A B G$ control during the October trial is linearly related to application frequency $(P>0.0001 ;$ Fig. 3$)$. In the October trial, applications applied every 2 weeks gave outstanding control and the level of control decreased as applications were applied more frequently (Fig. 3).

Kentucky bluegrass injury. Damage to KBG and other desirable turf species is undesirable, but the injury was minor on the cultivars used in our studies and recovery occurs quickly after applications stop. Because mesotrione symptoms occur in new growth, damaged tissue is quickly removed through mowing after applications stop. Fur- ther research into the addition of a safening agent may help to reduce the negative aesthetic results from mesotrione but maintain weed control. Further research is also needed on cultivar sensitivity to mesotrione, particularly because KBG is a variable species with a wide selection of cultivars. Some research on cultivar tolerance to mesotrione in KBG has been reported (Bhowmik et al., 2007), however, not under the application regimes used in this research. The most effective application regimes for $\mathrm{ABG}$ control should be expected to increase the risk of injury to susceptible KBG cultivars.

Mesotrione can provide effective ABG control if multiple applications are made when air temperatures are consistently above $20^{\circ} \mathrm{C}$. Seven to 10 applications at low rates of mesotrione can be used any time throughout

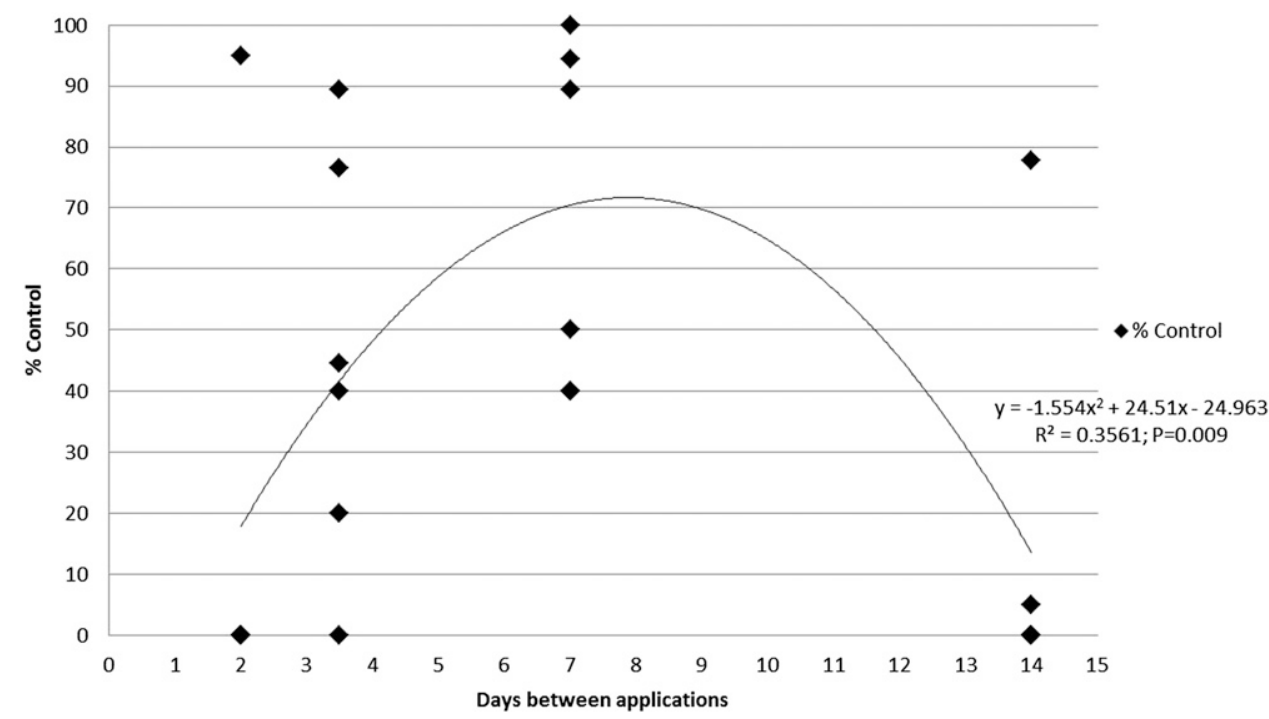

Fig. 2. Effect of application frequency on annual bluegrass control from mesotrione at $186 \mathrm{~g} \cdot \mathrm{ha}^{-1}$ from the June and July 2010 field trials. Annual bluegrass exhibits a quadratic response with a maximum control level at $7.8 \mathrm{~d}$.

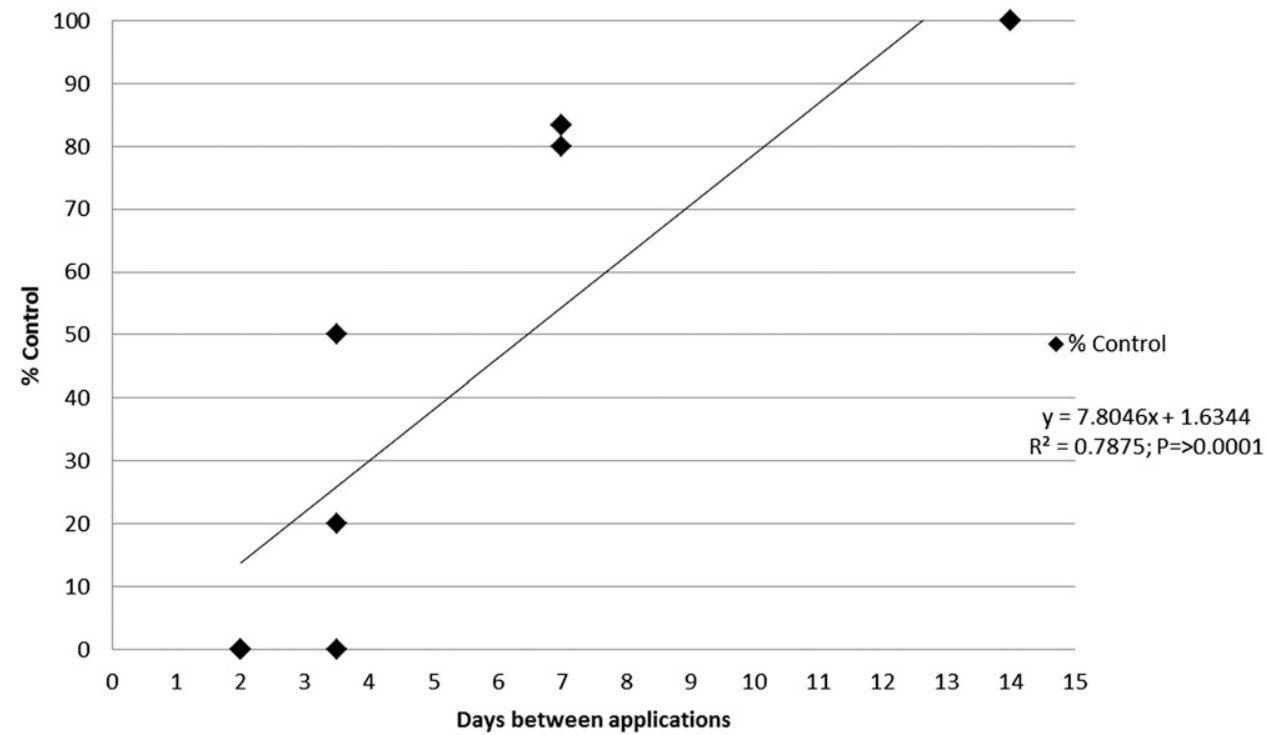

Fig. 3. Effect of application frequency on annual bluegrass control from mesotrione at $186 \mathrm{~g} \cdot \mathrm{ha}^{-1}$ from the Oct. 2010 field trial. Annual bluegrass showed a linear response with control levels increasing as the number of days between applications increases. 
the year to achieve high levels of control, but this is a very labor-intensive approach. Using five applications twice per week at $110 \mathrm{~g} \cdot \mathrm{ha}^{-1}$ or three applications at $186 \mathrm{~g} \cdot \mathrm{ha}^{-1}$ per week when the temperature is above $20^{\circ} \mathrm{C}$ may control $\mathrm{ABG}$ and is more practical for many turf managers. Good ABG control can be achieved in the fall as air temperatures are declining, but applications should be at higher rates with longer intervals between applications. A successful regimen using mesotrione to control $\mathrm{ABG}$ in $\mathrm{KBG}$ will have to be based on desired control levels, tolerance of injury to the desired turf, amount of labor required, and time of year the herbicide will be applied.

\section{Literature Cited}

Abit, M.J. and K. Al-Khatib. 2009. Absorption, translocation, and metabolism of mesotrione in grain sorghum. Weed Sci. 57:563-566.

Anonymous. 2009. Tenacity 4S herbicide. Syngenta Professional Products, Greensboro, NC.

Armel, G.R., R.J. Richardson, H.P. Wilson, and T.E. Hines. 2009. Strategies for control of horseweed (Conyza canadensis) and other winter annual weeds in no-till corn. Weed Technol. 23:379383.

Beard, J., P. Rieke, A. Turgeon, and J. Vargas, Jr. 1978. Annual bluegrass (Poa annua L.) description, adaptation, culture, and control. Agricultural Experiment Station, East Lansing, MI.

Beaudegnies, R., A.J. Edmunds, T.E. Fraser, R.G. Hall, T.R. Hawkes, G. Mitchell, J. Schaetzer, S. Wendeborn, and J. Wibley. 2009. Herbicidal 4hydroxyphenylpyruvate dioxygenase inhibitorsA review of the triketone chemistry story from a Syngenta perspective. Bioorg. Med. Chem. 17:4134-4152.

Bhowmik, P., J. Ebdon, and D. Sarkar. 2007. Tolerance of kentucky bluegrass cultivars to mesotrione. 2007 annual meeting abstracts. ASA, CSSA, and SSSA, Madison, WI.

Branham, B., J. Skelton, and W. Sharp. 2010. Mesotrione controls Poa annua L. postermergence in kentucky bluegrass. ASA, CSSA, and SSSA 2010 Intl. Annu. Meetings, Long Beach, CA, 31 Oct. to 4 Nov. 2010.

Corbett, J., S. Askew, W. Thoma, and J. Wilcut. 2004. Weed efficacy evaluations for bromoxynil, glufosinate, glyphosate, pyrithiobac, and sulfosate. Weed Technol. 18:443-453.

Hoiberg, A.H. and D.D. Minner. 2010. Mesotrione reduces presence of annual bluegrass during fairway conversion. ASA, CSSA, and SSSA 2010 Intl. Annu. Meetings, Long Beach, CA, 21 Oct. to 4 Nov. 2010.

Johnson, B.C. and B.G. Young. 2002. Influence of temperature and relative humidity on the foliar activity of mesotrione. Weed Sci. 50:157161.

Kuehl, R.O. 2000. Design of experiments: Statistical principles of research design and analysis. Brooks/Cole, Belmont, CA.

McCurdy, J.D., J.S. McElroy, D.A. Kopsell, C.E. Sams, and J.C. Sorochan. 2008. Effects of mesotrione on perennial ryegrass (Lolium perenne L.) carotenoid concentrations under varying environmental conditions. J. Agr. Food Chem. 56:91339139.

Mitchell, G., D.W. Bartlett, T.E.M. Fraser, T.R. Hawkes, D.C. Holt, J.K. Townson, and R.A. Wichert. 2001. Mesotrione: A new selective herbicide for use in maize. Pest Manag. Sci. 57:120-128.

Reicher, Z., D. Weisenberger, D. Morton, B. Branham, and W. Sharp. 2011. Fall applications of mesotrione for annual bluegrass control in kentucky bluegrass. Appl. Turfgrass Sci. DOI: 10.1094/ ATS-2011-0325-01-RS.

SAS. 2008. SAS/STAT User's Guide. Version 9.2. SAS Institute, Cary, NC. 